\title{
The influence of the aeration status (ODR, Eh) of peat soils on their ability to produce methane
}

\author{
Anna Szafranek-Nakonieczna $\cdot$ Zofia Stępniewska
}

Received: 27 January 2014/ Accepted: 24 January 2015/Published online: 7 February 2015

(C) The Author(s) 2015. This article is published with open access at Springerlink.com

\begin{abstract}
Methane is a greenhouse gas having wellknown impacts on global radiative forcing. However, understanding the dynamics and thresholds of methane formation in peatlands, which undergo cyclic aeration and anoxia, is currently limited even though it is crucial for reliable estimation of methane emission to the atmosphere. The purpose of this study was to estimate the optimal range and thresholds of aeration conditions, which impact methane formation in upper layers of peat originating from a natural fen (East Poland). The experiment was conducted under laboratory conditions on two groups of differently treated soils which were incubated at field water capacity. One group was incubated in air and another in helium, both at temperatures of 5,10 and $20^{\circ} \mathrm{C}$. Direct soil aeration estimation included measurements of redox potential and oxygen diffusion rate. The latter was used for the first time as an indicator of methane formation in soil. Both the aerated and anoxic groups showed that methane formation took place at ODR of below $20 \mu \mathrm{g} \mathrm{O}_{2} \mathrm{~m}^{-2} \mathrm{~s}^{-1}$ and Eh of below $+240 \mathrm{mV}$ which are the higher threshold levels for methanogenesis than previously reported. Maximum methanogenic activity amounted up to $71.86 \mathrm{mg} \mathrm{CH}_{4} \mathrm{kgDW}^{-1}$ $\mathrm{d}^{-1}$. Aeration was capable of reducing this
\end{abstract}

A. Szafranek-Nakonieczna $(\bowtie) \cdot$ Z. Stępniewska Department of Biochemistry and Environmental Chemistry, The John Paul II Catholic University of Lublin, Konstantynów 1I, 20-708 Lublin, Poland e-mail: anna.szafranek@kul.lublin.pl methanogenic activity by $28-100 \%$. Decreasing temperatures and aeration increased the time until the initiation of $\mathrm{CH}_{4}$ production $(p<0.05, \mathrm{n}=72)$.

Keywords Methanogenesis - Peat soil - Oxygen diffusion rate $\cdot$ Redox potential $\cdot$ Aeration thresholds

\section{Introduction}

Methane $\left(\mathrm{CH}_{4}\right)$ is one of the main greenhouse gases playing an important role in Earth's climate radiative forcing (Forster et al. 2007). Despite its lower concentration relative to $\mathrm{CO}_{2}$, it is 25-times more efficient in infrared energy absorption over a 100-year time frame (Forster et al. 2007). Methanogens are microbes responsible for methane production and they belong to the Archaea domain. These microorganisms are regarded as strictly anaerobic and gain energy for growth by utilizing a limited number of chemical substrates such as hydrogen, carbon dioxide, formate, ethanol, methanol, methylamines and acetate in methane production (Demirel and Scherer 2008). Their metabolism involves many $\mathrm{O}_{2}$-sensitive redox centres, such as $\mathrm{Fe}-\mathrm{S}$ clusters present in almost every metalloenzyme involved in all of the three pathways of methanogenesis, i.e. $\mathrm{H}_{2} / \mathrm{CO}_{2}$, aceticlastic, and methylotrophic, used for electron transport and/or catalysis (Glass and Orphan 2012; Tholen et al. 2007). The presence of oxygen leads to formation of reactive 
oxygen species, which can damage cell membranes, DNA, and proteins within methanogens. Oxygen also causes an irreversible dissociation of the $\mathrm{F}_{420}$-hydrogenase enzyme complex, a crucial electron transporter in methanogens (Angel et al. 2011). Various physicochemical factors such a temperature, $\mathrm{pH}$, substrate availability or aeration have been proposed for controlling the activity of methanogens in wetlands (Glass and Orphan 2012; Singh 2001).

When methanogenic activity is investigated in the context of sensitivity to oxygen, a good indicator of aeration is required. One of the parameters commonly used in investigations of methanogenic activity is redox potential (Eh), which expresses the tendency of environment to receive or supply electrons in the solution. Electron transfer between donors and acceptors is involved in various redox reactions. As long as the system is exposed to the ambient atmosphere, $\mathrm{O}_{2}$, as an electron acceptor, is responsible for high Eh. In the absence of $\mathrm{O}_{2}$, a decline in redox potential and reduction of oxidized forms $\left(\mathrm{NO}_{3}^{-}, \mathrm{Mn}^{4+}, \mathrm{Fe}^{3+}\right.$, and $\mathrm{SO}_{4}^{2-}$ ) takes place. Eh is widely regarded as a useful tool for environment quality research (Stępniewski et al. 2005; Yu et al. 2006). In peat and waterlogged soils, Eh below $+350 \mathrm{mV}$ is expected (Pezeshki 2001), while generally in well-aerated soils it can reach $+700 \mathrm{mV}$ (Bennicelli et al. 2006; Yu et al. 2006). In wetland soils, the range of Eh values commonly range from +700 to $-300 \mathrm{mV}$. Soils with Eh above $+300 \mathrm{mV}$ are regarded as aerobic, while below $+300 \mathrm{mV}$ as anaerobic (Inglett et al. 2005). It is reported that reduced conditions are required for the activation of methanogens (Öquist and Sundh 1998; Singh 2001). Another way for assessing aeration state is measuring $\mathrm{O}_{2}$ concentration ( $\mathrm{Yu}$ et al. 2006). Incubation experiments can use chromatographic measurements of oxygen concentration in the headspace over soil samples but this technique has challenges due to the different moisture of soils. These variations in soil moisture can have significant effects on soil aeration. Low moisture allows for easier access of the above-surface air to soil through pores, whereas at higher water content, diffusion of oxygen can become constrained due to the low solubility of oxygen in water (Kechavarzi et al. 2010). It is commonly known that diffusion of gases in water is approximately $10^{4}$-times slower than in air (Riutta 2008). At atmospheric pressure and temperature of $25{ }^{\circ} \mathrm{C}$, air saturated water contains about $250 \mu \mathrm{mol} \mathrm{O}_{2}$ per liter. Increase of temperature and salinity resulted in decrease of water saturation (Brune et al. 2000). In this context, oxygen diffusion rate (ODR) seems to be an accurate and useful tool for investigation of aeration in different soils, and can be used both in laboratory and in situ for $\mathrm{O}_{2}$ measurements (Minamikawa and Sakai 2005; Stępniewski et al. 2005; Bennicelli et al. 2006). Since methanogens are extremely sensitive to oxygen, ODR measurements can be useful for investigation of methanogenic activity in soils and particularly in organic soils such as peat. Typically an ODR value above $35 \mu \mathrm{g} \mathrm{O}_{2}$ $\mathrm{m}^{-2} \cdot \mathrm{s}^{-1}$ represents good soil aeration conditions, while below this value aeration it becomes limited (Stępniewski et al. 2000; Czyż 2004).

Peat soils are known as sources of atmospheric methane, and their oxygen status is an important factor influencing methane production rates. There are several publications reporting that methanogens can survive oxygen stress and remain active even in relatively oxygenated environments such as rice paddy soils, deserts, oxygenated water and peat soils (Freeman et al. 2002; Kim et al. 2008; Yuan et al. 2009; Angel et al. 2011; Grossart et al. 2011) and become active at the onset of anaerobic conditions. Temporal aeration of peatland influenced $\mathrm{CH}_{4}$ emission but also carbon release as a $\mathrm{CO}_{2}$. Climate change results in drought in the summer or significant lowering of groundwater in many regions of the world. It is also the case in East and Central Europe, including Poland, and implies that there is more frequent decrease in water levels resulting in more frequent aeration of peats during the year. The drought could reduce the capacity of wetlands to serve as sinks of global carbon and turn them into sources of atmospheric carbon because of faster organic matter mineralisation, when oxygen plays a role of a major electron acceptor. Recent studies have shown that in some peats (UK) the $\mathrm{CO}_{2}$ emission during drought remains unchanged or increases even by $181 \%$ and after re-submergence raise by $500 \%$ in relation to the time before the drought (Fenner and Freeman 2011). Understanding these differential responses of carbon mineralization in peatlands is crucial for understanding their role in the global climate.

The four aims of this study were: (1) to investigate how methanogenic activity in a peatland is affected by the aeration state described by Eh, and ODR; (2) to find what are the threshold values of Eh and ODR for 
methane formation initiation; (3) to determine how temperature impacts these threshold values; and (4) to reveal which levels of a peat profile are more sensitive to aeration.

\section{Materials and methods}

Study site description

The experiment was carried out using peat material collected from a Garbatówka fen, a part of Ciesacin Reserve (Polesie Lubelskie, East Poland, $51^{\circ} 21^{\prime} \mathrm{N}$, $23^{\circ} 6^{\prime} \mathrm{E}$ ), characterized by a high groundwater table $(+5 \mathrm{~cm})$ resulting in high moisture and presence of numerous small water bodies. A 195 ha peatland area is situated in the catchment basins of eutrophic lakes: Uściwierzek, Uściwierz, Rotcze, and Sumin and borders agricultural soils in the south (Fig. 1). Vegetation is mainly composed of Carex spp., Phragmites spp., Juncus spp., Schoenoplectus spp., and some species of Bryophytes (Szafranek-Nakonieczna and Bennicelli 2010). Peat material was collected from three representative plots (according to prevailing vegetation, which was similar throughout the fen area), where four horizons of the peat profile layered at every $20 \mathrm{~cm}$ from the top to the depth of $80 \mathrm{~cm}$ (i.e. 0-20, 20-40, 40-60, 60-80 cm) were sampled. Samples were collected in September 2009, transported in tightly closed PVC containers, and stored in the laboratory at $4{ }^{\circ} \mathrm{C}$ for further analysis within
2-3 days. Further details on the soil treatment protocol are provided in Szafranek-Nakonieczna and Bennicelli (2010).

Physicochemical analysis of soil material

Dry weight of the peat material and its water content (three replicates for each layer) were determined by weighing peat before and after drying at $105{ }^{\circ} \mathrm{C}$ for $48 \mathrm{~h}$. The decomposition degree of peat was classified as from $\mathrm{H} 1$ (peat being pristine, undecomposed, and fibrous) to H10 (fully decomposed, humified peat) on the basis of the von Post index (Glatzel et al. 2004). Total organic carbon (TOC) was determined in dry peat samples by combustion and the analysis of evolved $\mathrm{CO}_{2}$ by means of TOC-V $\mathrm{V}_{\mathrm{CSH}}$ with SSM5000A module (Shimadzu, Japan). Bioavailable forms of $\mathrm{N}$ and $\mathrm{P}$ were measured in extracts: peat-water for nitrite and nitrate ( $35 \mathrm{~g}$ soil in $100 \mathrm{ml}$ of water), peat$\mathrm{NaCl}(35 \mathrm{~g}$ soil in $100 \mathrm{ml}$ of $0.2 \mathrm{M} \mathrm{NaCl})$ for ammonium, and peat- $\mathrm{NaHCO}_{3}(5 \mathrm{~g}$ soil in $100 \mathrm{ml}$ of $0.5 \mathrm{NaHCO}_{3}$ ) for phosphorus using an AA3 autoanalyzer, (Braun + Luebbe, Germany), after filtering through filter paper (Munktell, grade 390, Germany) according to the method described by Banach et al. (2009).

Redox potential (Eh) and $\mathrm{pH}$ were measured directly after opening the incubation bottles by means of a multifunctional potential meter pIONeer 65 equipped with a combined platinum and $\mathrm{Ag} / \mathrm{AgCl}$ (reference) electrode or with a glass electrode

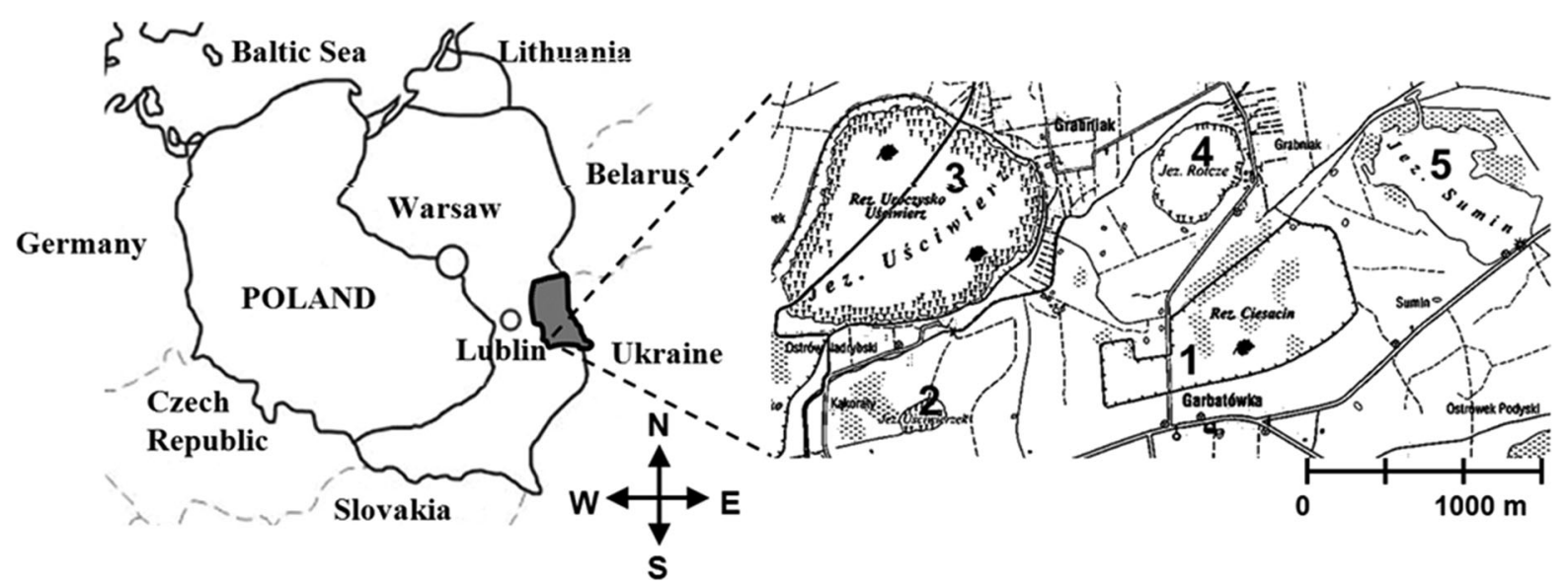

Fig. 1 Location of the tested fen-Garbatówka (1), and surrounding water bodies: Uściwierzek Lake (2), Uściwierz Lake (3), Rotcze Lake (4), Sumin Lake (5) 
(E31M004 and Cartrode pH E16M340, Radiometer Analytical S.A., France). Final Eh was corrected for $\mathrm{pH}$ values according to a pattern reported by Bennicelli et al. (2006).

ODR was determined by the amperometric method elaborated by Lemon and Erickson (1952). The method consists of measurement of the amount of oxygen diffusing to the surface of a platinum wire electrode, where it is reduced electrochemically. The platinum electrode is therefore a model of center absorbing oxygen, and the intensity of oxygen flux to the electrode indicates the maximum amount of oxygen that would be available for soil microorganisms. The value of the oxygen reduction current on the platinum electrode rate is expressed as the oxygen diffusion rate (ODR):

$\operatorname{ODR}\left[\mu g \mathrm{O}_{2} \mathrm{~m}^{-2} \mathrm{~s}^{-1}\right]=8.29 \times 10^{-5} \frac{i}{\mathrm{~A}} \frac{[\mu \mathrm{A}]}{\left[\mathrm{mm}^{2}\right]}$

where: $i$ current in $\mu \mathrm{A}, A$-area of the electrode in $\mathrm{mm}^{2}$ (Stępniewski et al. 2005).

Incubation experiment

Twenty-cm layers from 3 cores of peat were mixed together. Peat material was placed in dark sterile bottles $(60 \mathrm{~mL})$, tightly closed (with a septum and aluminium cap) and incubated in dark conditions, under two treatments: aerated (AT) with a natural water content combined with ambient air and anoxic (AN) without oxygen treatment, where soil was incubated in helium (AN). An anoxic environment was created by replacement of air with helium (purity $99.999 \%$, Praxair, Poland). The peat samples from each layer were incubated under AT and AN conditions at three temperatures: 5,10 , and $20{ }^{\circ} \mathrm{C}$ for up to 300 days. The incubation temperatures were selected on the basis of mean seasonal temperatures (spring $12{ }^{\circ} \mathrm{C}$, autumn $5{ }^{\circ} \mathrm{C}$ and summer $19{ }^{\circ} \mathrm{C}$ ) in the investigated region (Szafranek-Nakonieczna and Bennicelli 2010). Sixty replicates for each treatment were prepared in order to allow all necessary measurements in three replicates to minimize the random error.

The concentration of methane in the headspace was determined by the gas chromatography technique (Varian GC 3800, USA) with a flame ionization detector-FID (Szafranek-Nakonieczna and Bennicelli
2010). Methane production was recorded in $\mathrm{mg}$ of methane per gram of dry peat material $\left(\mathrm{mg} \mathrm{CH}_{4}\right.$ $\mathrm{gDW}^{-1}$ ). During incubation of the peat samples, the methane concentration in the headspace as well as aeration parameters (ODR, Eh) were measured up to 300 days (at the beginning, on the $3 \mathrm{rd}$, 7th day, and next every 14-21 days, a total of 20-times, always in three replicates. After determination of the Eh and ODR values, the samples were no longer incubated and were eliminated from the investigations.

Statistical analysis

Collected data were statistically evaluated using a Statistica 9.1 (Systat Soft Inc., USA) package. Prior to the analysis all data were tested for the normality (Shapiro-Wilk test) and homogeneity of variances (Levene's test). If necessary a $\ln (x+1)$ transformation was applied. In order to explore variation of peat characteristics by depth a one-way ANOVA test with Tukey procedure as post hoc was used.

The dynamics of methane concentration, Eh, and ODR were visualised using the Sigma Plot 10.0 software (Systat Soft Inc., USA) where regression models were applied to data and resulted in regression equations and the goodness of fit statistics $\left(R^{2}\right)$ with their significance. The methane concentration observed during the experiment (as a cumulative concentration) was expressed in mg methane per $\mathrm{g}$ of dry peat material. The relationships between concentration of formed methane and aeration indicators were assessed using a correlative approach: first, a correlation matrix was generated and significant correlations were further studied by means of correlation coefficient (Pearson's or Spearman's rho depending on data normality).

The final analysis revealed which of experimental variables (depth in profile, temperature and aeration conditions) play a significant role in methane generation (in terms of activation time and methanogenic activity). For this study a three-way ANOVA with Tukey within-group test for each factor was used. For better clarity of understanding separate effects of studied factors were omitted for any possible interactions. The significance level of all tests was accepted at $p<0.05$. The results were presented as means of nontransformed data.

The methanogenic activity (MGA) rate was calculated by a linear regression of the increase of methane concentration in time and expressed as $\mu \mathrm{g}$ of produced 
methane per mass of dry peat material and per day ( $\mu \mathrm{g}$ $\mathrm{CH}_{4} \mathrm{kgDW}^{-1} \cdot \mathrm{d}^{-1}$ ) (Yu et al. 2007; Freitag and Prosser 2009).

\section{Results and discussion}

Physicochemical properties of peat soils

Soil physicochemical characteristics are summarized in Table 1. All depths in the investigated profile differed significantly with respect to moisture and total organic carbon (TOC) content. The highest moisture was observed in the deepest layer while the highest TOC at depth 40-60 cm. Decomposition degree was somewhat low in levels 0-20 and 20-40 cm, described as $\mathrm{H} 2$ by the von Post index (below $40 \mathrm{~cm}$ as $\mathrm{H} 3$ ). In case of biogenic $\mathrm{N}, \mathrm{NO}_{3}{ }^{-}$forms, the concentration in depths $40-80 \mathrm{~cm}$ was, by a factor of two, greater than in the $0-40 \mathrm{~cm}$ levels. Distribution of other forms of $\mathrm{N}$ and $\mathrm{P}$ was similar in all profiles as was $\mathrm{pH}$ which was almost perfectly neutral in a narrow range of 6.77-6.93.

\section{Changes in aeration conditions (Eh and ODR} results)

Changes of Eh and ODR during experiment are described by exponential regressions (Fig. 2, equations in Table 2). During incubation, decreasing Eh values were noted in each of the treatments. A more sudden decrease (maximally by $200 \mathrm{mV}$ ) under the AN was found, while under the AT treatment, the change in Eh was 10-times smaller (Fig. 2). This was the effect of lack of molecular oxygen under the AN conditions and its rapid utilization by aerobic microorganisms in peat soil, while $\mathrm{O}_{2}$ diffusion in the AT treatment was very slow but it did occur. Therefore, at the end of the experiment a higher drop of redox potential (to $-100 \mathrm{mV}$ ) was found in peat material incubated without oxygen than in that incubated in air, where Eh decreased to $0 \mathrm{mV}$ (Fig. 2). The low Eh values have a positive effect on the activity of methanogens (reflected as an increase of methane concentration in the headspace) in all the methanogenically active samples (exponential model, $\mathrm{y}=\mathrm{a} \exp (-\mathrm{bx}), p<0.05$, Table 3, Fig. 2) This was earlier also reported by other researchers in rice paddies fields and peats (e.g. Minamikawa and Sakai 2005; Bennicelli et al. 2006, Yu et al. 2006).

Generally in wetland soils critical values of Eh limiting the activity of methanogens seems to be well investigated. But in the case of peat soil there is little available data. Paddy soils appear to be the most recognized. The researchers provide a diverse range of values for the Eh thresholds which is as wide as +400 to $-300 \mathrm{mV}$ (see Table 4 for the comparative summary). The differences in Eh thresholds are observed often within the same kind of soils such as paddy soils, but also in natural wetlands as well as in medium cultures. However, it is still commonly used as an indicator of soil methanogenesis (Yao et al. 1999; Lyimo et al. 2002; Yu et al. 2006).

In investigated peat soils, methane (at the concentration of $2 \mathrm{ppm}$ ) in the headspace was detected when Eh dropped to $+240 \mathrm{mV}$ under AT and $+112 \mathrm{mV}$ under AN treatments (Table 3; Fig. 3), and the values were generally higher than those found in natural wetlands (Table 4). The differences in Eh conditions suitable for activation of methanogens in both the AT and AN treatments (Fig. 2) suggest that methanogens can adapt to aerated conditions (i.e. presence of molecular oxygen). This seems possible particularly when the time of methanogenesis activation is compared in the investigated profiles, where under AT treatment the lag time was 8- to 10-times longer than in AN (Fig. 4). The structure of peat provides protective

Table 1 Characteristics of the peat materials

\begin{tabular}{|c|c|c|c|c|c|c|c|c|}
\hline \multirow[t]{2}{*}{ Depth $(\mathrm{cm})$} & \multirow[t]{2}{*}{$\mathrm{pH}\left(\mathrm{H}_{2} \mathrm{O}\right)$} & \multirow[t]{2}{*}{ Moisture $\left(\mathrm{g} \mathrm{g}^{-1}\right)$} & \multirow[t]{2}{*}{ TOC $(\%)$} & \multirow{2}{*}{$\begin{array}{l}\text { Decomposition degree } \\
\text { (von Post index) }\end{array}$} & \multicolumn{4}{|c|}{$\left(\mathrm{mg} \mathrm{kgDW}^{-1}\right)$} \\
\hline & & & & & $\mathrm{NO}_{2}^{-}$ & $\mathrm{NO}_{3}^{-}$ & $\mathrm{NH}_{4}^{+}$ & $\mathrm{PO}_{4}^{-3}$ \\
\hline $0-20$ & $6.93 a$ & $5.93 c$ & $42.7 \mathrm{c}$ & $\mathrm{H} 2$ & $0.67 \mathrm{a}$ & $4.34 \mathrm{a}$ & $5.62 \mathrm{a}$ & $14.47 \mathrm{a}$ \\
\hline $20-40$ & $6.80 \mathrm{a}$ & $5.30 \mathrm{a}$ & $39.2 \mathrm{a}$ & $\mathrm{H} 2$ & $0.46 \mathrm{~b}$ & $4.79 a$ & $5.84 a$ & $11.95 \mathrm{a}$ \\
\hline $40-60$ & $6.83 \mathrm{a}$ & $5.82 \mathrm{~b}$ & $44.9 \mathrm{~d}$ & $\mathrm{H} 3$ & $0.59 \mathrm{ab}$ & $8.36 \mathrm{~b}$ & $5.63 \mathrm{a}$ & $11.14 \mathrm{a}$ \\
\hline $60-80$ & $6.77 \mathrm{a}$ & $6.67 \mathrm{~d}$ & $41.8 b$ & H3 & $0.51 \mathrm{ab}$ & $9.90 \mathrm{~b}$ & $5.18 \mathrm{a}$ & $10.13 a$ \\
\hline
\end{tabular}

Values followed by the same letter are not significantly different (ANOVA, $p<0.05$ ), $\mathrm{n}=3$ 


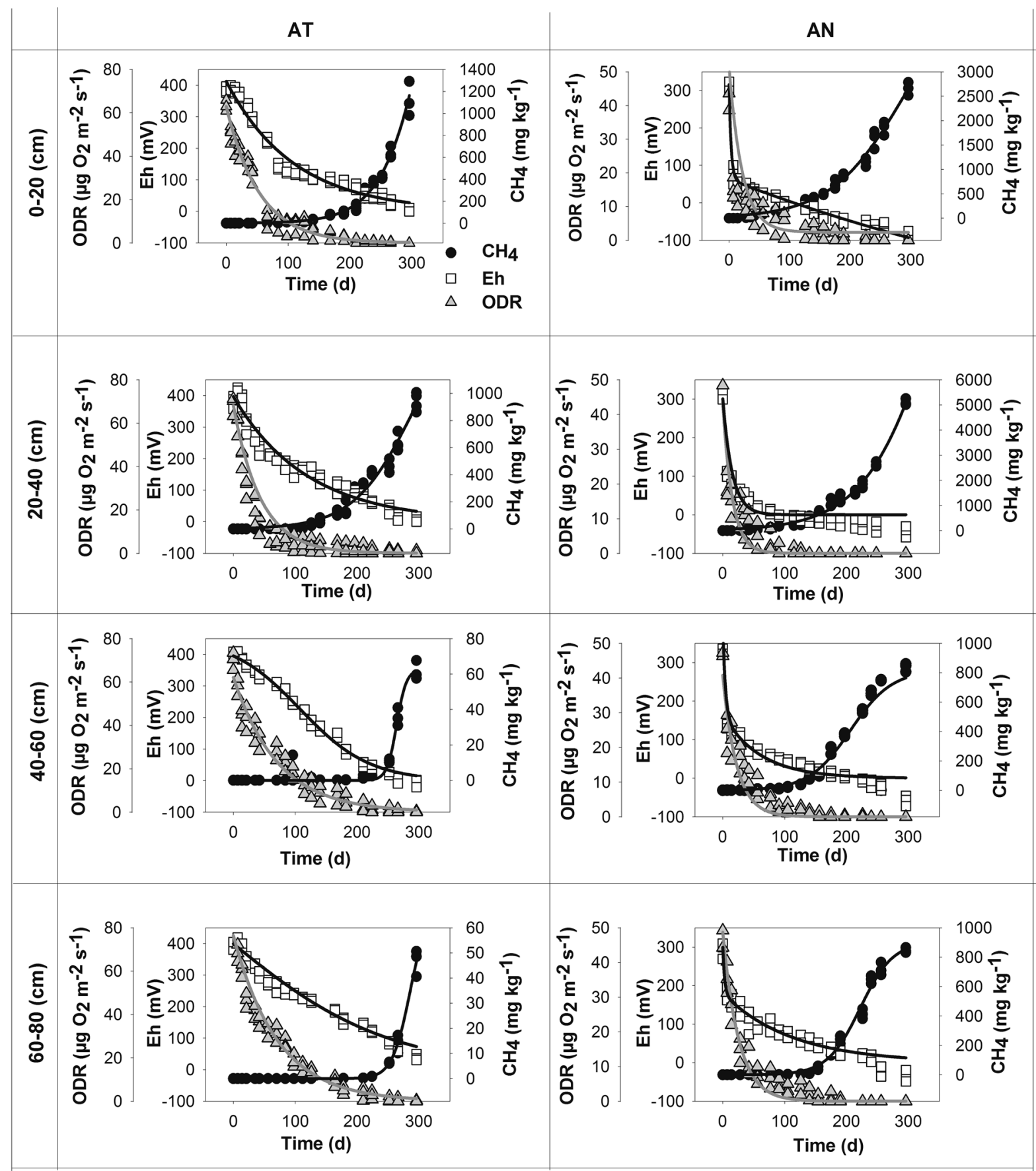

Fig. 2 Dynamics of methane formation, variation of ODR and Eh at $20^{\circ} \mathrm{C}$ during aerated (AT) and anoxic (AN) treatment at particular depths $(n=60)$

conditions for methanogens, or methanogens possess their own protective mechanisms; e.g. antioxidant enzymes to protect them against oxygen (Erkel et al. 2006; Yu et al. 2007; Morozova and Wagner 2007).
The high values of ODR and Eh recorded at the beginning of the experiment (in the AN treatment), were related to the short time sufficient for oxygenation of peat samples during preparation of incubation 
Table 2 Equations of regression describing the change of methane concentration, redox potential (Eh) and oxygen diffusion rates (ODR) in time at aerated (AT) and anaerobic (AN) treatments

\begin{tabular}{|c|c|c|c|c|c|}
\hline \multirow[t]{2}{*}{ Depth } & \multirow[t]{2}{*}{ Parameter } & \multicolumn{2}{|l|}{ AT } & \multicolumn{2}{|l|}{ AN } \\
\hline & & Equation & $R^{2}$ & Equation & $R^{2}$ \\
\hline \multirow[t]{3}{*}{$0-20$} & $\mathrm{CH}_{4}$ & $\mathrm{y}=355.66 /(1+\exp (-(\mathrm{x}-358.25) / 41.59))$ & 0.98 & $\mathrm{y}=5155.86 /(1+\exp (-(x-292.3) / 61.67))$ & 0.98 \\
\hline & Eh & $y=419.593 \exp (-0.0097 x)$ & 0.97 & $\mathrm{y}=281.313 \exp (-0.0489 x)$ & 0.50 \\
\hline & ODR & $y=62.9197 \exp (-0.0187 x)$ & 0.97 & $y=35.6012 \exp (-0.0460 x)$ & 0.77 \\
\hline \multirow[t]{3}{*}{$20-40$} & $\mathrm{CH}_{4}$ & $\begin{array}{l}y=730.1 /(1+\exp (-x-290.36) / \\
48.26))\end{array}$ & 0.97 & $y=19418.21 /(1+\exp (-(x-358.21) / 60.1))$ & 0.99 \\
\hline & Eh & $y=396.574 \exp (-0.0084 x)$ & 0.96 & $y=300.549 \exp (-0.066 x)$ & 0.95 \\
\hline & ODR & $y=68.0830 \exp (-0.0226 x)$ & 0.97 & $y=43.3931 \exp (-0.0647 x)$ & 0.89 \\
\hline \multirow[t]{3}{*}{$40-60$} & $\mathrm{CH}_{4}$ & $\begin{array}{l}\mathrm{y}=2.7 /(1+\exp (-(\mathrm{x}--63.9) / \\
7.86))\end{array}$ & 0.97 & $\mathrm{y}=816.96 /(1+\exp (-(\mathrm{x}-206.37) / 33.48))$ & 0.88 \\
\hline & Eh & $\mathrm{y}=439.9872 \exp (-0.0076 \mathrm{x})$ & 0.94 & $\mathrm{y}=246.0573 \exp (-0.0278 \mathrm{x})$ & 0.81 \\
\hline & ODR & $y=62.1742 \exp (-0.0140 x)$ & 0.97 & $y=40.7713 \exp (-0.0448 x)$ & 0.92 \\
\hline \multirow[t]{3}{*}{$60-80$} & $\mathrm{CH}_{4}$ & $\begin{array}{l}\mathrm{y}=69.46 /(1+\exp (-(\mathrm{x}-285.69) / \\
14.53))\end{array}$ & 0.99 & $\mathrm{y}=906.64 /(1+\exp (-(\mathrm{x}-222.1) / 26.53))$ & 0.99 \\
\hline & Eh & $y=406.5303 \exp (-0.0057 x)$ & 0.97 & $\mathrm{y}=227.2747 \exp (-0.0128 \mathrm{x})$ & 0.87 \\
\hline & ODR & $\mathrm{y}=76.3911 \exp (-0.0140 x)$ & 0.96 & $y=48.6916 \exp (-0.039 x)$ & 0.98 \\
\hline
\end{tabular}

All regressions significant at $p<0.05, \mathrm{n}=60$

(in atmospheric air), but an immediate decrease was observed after flushing with helium. At the beginning of the experiment, the ODR values were between 55 and $70 \mu \mathrm{g}_{2} \quad \mathrm{~m}^{-2} \cdot \mathrm{s}^{-1}$ irrespective of the peat sampling depth and achieved final levels of $0 \mu \mathrm{g} \mathrm{O}_{2}$ $\mathrm{m}^{-2} \mathrm{~s}^{-1}$ under both AT and AN conditions (Fig. 2). The values of ODR below $26 \mu \mathrm{g} \mathrm{O}_{2} \mathrm{~m}^{-2} \mathrm{~s}^{-1}$ at which methanogenesis processes started (Table 3) were lower than $35 \mu \mathrm{g} \mathrm{O}_{2} \mathrm{~m}^{-2} \mathrm{~s}^{-1}$ reported in the literature as the limiting threshold of good aeration conditions (Stępniewski et al. 2000; Czyż 2004). However, the intensification of methane formation took place when ODR was around $0 \mu \mathrm{g} \mathrm{O}_{2} \mathrm{~m}^{-2} \cdot \mathrm{s}^{-1}$, indicating a complete lack of oxygen in soil pores. Methane production potential was negatively correlated with the ODR values (Table 3), which was expected. We have confirmed that methanogens in the tested fen soils can be active irrespective of the strictly anoxic conditions reflected by ODR values e.g. higher than $0 \mu \mathrm{g}$ of $\mathrm{O}_{2}$ per $\mathrm{m}^{2} \mathrm{~s}^{-1}$ (Table 3 ). The average values of ODR for methane formation (to the headspace concentration of $2 \mathrm{ppm}$ ) at $20{ }^{\circ} \mathrm{C}$ under the AT treatment were ca. $20 \mu \mathrm{g} \mathrm{O}_{2} \mathrm{~m}^{-2} \cdot \mathrm{s}^{-1}$, while under the AN treatment, they were slightly lower $(<17 \mu \mathrm{g}$ $\mathrm{O}_{2} \mathrm{~m}^{-2} \mathrm{~s}^{-1}$ ) (Fig. 3).
There are currently no data about the relation of ODR to methanogenic activity. To study the effect of peat aeration, drainage or rewetting on methanogenesis most researchers used oxygen concentration measurements either in the headspace of investigated samples or in situ chambers as an indicator or by manipulation of water level (Freeman et al. 2002; Yu et al. 2006; Dowrick et al. 2006). Taking into account soil properties, small size of measuring electrodes and possibility of direct measurement, ODR is a convenient alternative for the existing methods of Eh. We found significant negative relationships $(p<0.001$, Table 3) between ODR and cumulative methane in the headspace of the investigated peat soils in the tested treatments (except at $5{ }^{\circ} \mathrm{C}$ under the AT conditions, where no methane was detected). Positive and statistically significant relationships $(p<0.001)$ between ODR and Eh were also found (Table 3) suggesting that these two parameters can be considered for approximating methane emission potentials.

Methane formation and methanogenic activity

Directly after flushing the bottles, the composition of gases was assessed and no methane in the headspace of 
Table 3 The methane detection time (days, MD) and associated values of aeration parameters (ODR, Eh)

\begin{tabular}{|c|c|c|c|c|c|c|c|c|c|}
\hline & $\mathrm{T}\left({ }^{\circ} \mathrm{C}\right)$ & $\begin{array}{l}\text { Depth } \\
(\mathrm{cm})\end{array}$ & MD (day) & $\begin{array}{l}\text { ODR } \\
\left(\mu \mathrm{g} \mathrm{O}_{2} \mathrm{~m}^{-2} \mathrm{~s}^{-1}\right)\end{array}$ & Eh $(\mathrm{mV})$ & M-Eh & M-ODR & Eh-ODR & $\begin{array}{l}\operatorname{MGA}\left(\mu \mathrm{g} \mathrm{CH} \mathrm{CH}_{4}\right. \\
\left(\mathrm{kgDW}^{-1} \cdot \mathrm{d}^{-1}\right)\end{array}$ \\
\hline \multirow[t]{12}{*}{$\mathrm{AT}$} & \multirow[t]{4}{*}{5} & $0-20$ & - & $42 \mathrm{a}$ & $389 b$ & - & - & $0.30 * *$ & 0.0 \\
\hline & & $20-40$ & - & $49 b$ & $384 a$ & - & - & $0.85^{* * *}$ & 0.0 \\
\hline & & $40-60$ & - & $40 \mathrm{a}$ & $383 a$ & - & - & $0.83 * * *$ & 0.0 \\
\hline & & $60-80$ & - & $42 \mathrm{a}$ & $382 \mathrm{a}$ & - & - & $0.72 * * *$ & 0.0 \\
\hline & \multirow[t]{4}{*}{10} & $0-20$ & $217 \mathrm{a}$ & $14 \mathrm{a}$ & $194 \mathrm{c}$ & $0.83 * * *$ & $0.71 * * *$ & $0.74 * * *$ & $5.6 \mathrm{~b}$ \\
\hline & & $20-40$ & $231 b$ & $15 \mathrm{a}$ & $169 \mathrm{a}$ & $0.88 * * *$ & $0.58 * * *$ & $0.48 * * *$ & $6.6 c$ \\
\hline & & $40-60$ & $238 b$ & $16 \mathrm{a}$ & $184 b$ & - & - & $0.48 * * *$ & $1.8 \mathrm{a}$ \\
\hline & & $60-80$ & $259 \mathrm{c}$ & $17 \mathrm{a}$ & $190 \mathrm{c}$ & $0.74 * * *$ & $0.79 * * *$ & $0.83 * * *$ & $7.8 \mathrm{~d}$ \\
\hline & \multirow[t]{4}{*}{20} & 0-20 & $65 b$ & $12 \mathrm{a}$ & $225 a$ & $0.87 * * *$ & $0.93 * * *$ & $0.96^{* * *}$ & $15610.0 \mathrm{~d}$ \\
\hline & & $20-40$ & $35 a$ & $26 c$ & $240 \mathrm{c}$ & $0.86 * * *$ & $0.91 * * *$ & $0.95 * * *$ & $7875.0 \mathrm{c}$ \\
\hline & & $40-60$ & $70 \mathrm{~b}$ & $24 c$ & $240 \mathrm{c}$ & $0.91 * * *$ & $0.88 * * *$ & $0.97 * * *$ & $1755.0 \mathrm{~b}$ \\
\hline & & $60-80$ & $84 c$ & $19 b$ & $231 b$ & $0.62 * * *$ & $0.66 * * *$ & $0.85 * * *$ & $2720.0 \mathrm{a}$ \\
\hline \multirow[t]{12}{*}{ AN } & \multirow[t]{4}{*}{5} & $0-20$ & $65 b$ & $6 a$ & $64 a$ & $0.83 * * *$ & $0.87 * * *$ & $0.88 * * *$ & $20.3 a$ \\
\hline & & $20-40$ & $70 \mathrm{c}$ & $5 a$ & $82 b$ & $0.92 * * *$ & $0.90 * * *$ & $0.92 * * *$ & $244.8 b$ \\
\hline & & $40-60$ & $64 b$ & $6 a$ & $94 b$ & $0.69 * * *$ & $0.79 * * *$ & $0.92 * * *$ & $385.6 \mathrm{c}$ \\
\hline & & $60-80$ & $49 a$ & $6 a$ & $107 \mathrm{c}$ & $0.62 * * *$ & $0.98 * * *$ & $0.96 * * *$ & $512.0 \mathrm{~d}$ \\
\hline & \multirow[t]{4}{*}{10} & $0-20$ & $28 \mathrm{a}$ & $17 \mathrm{~b}$ & $70 \mathrm{a}$ & $0.90 * * *$ & $0.87 * * *$ & $0.71 * * *$ & $209.9 c$ \\
\hline & & $20-40$ & $28 \mathrm{a}$ & $13 a$ & $90 \mathrm{~b}$ & $0.69 * * *$ & $0.90 * * *$ & $0.96^{* * *}$ & $1179.4 d$ \\
\hline & & $40-60$ & $35 b$ & $14 \mathrm{a}$ & $100 \mathrm{c}$ & $0.88 * * *$ & $0.85 * * *$ & $0.85^{* * *}$ & $678.4 \mathrm{a}$ \\
\hline & & $60-80$ & $49 c$ & $13 a$ & $112 \mathrm{c}$ & $0.77 * * *$ & $0.85 * * *$ & $0.94 * * *$ & $443.8 b$ \\
\hline & \multirow[t]{4}{*}{20} & $0-20$ & $3 a$ & $15 \mathrm{a}$ & $90 \mathrm{a}$ & $0.20 *$ & $0.92 * * *$ & $0.67 * * *$ & $21560.0 \mathrm{~b}$ \\
\hline & & $20-40$ & $3 a$ & $18 \mathrm{~b}$ & $104 b$ & - & $0.96 * * *$ & $0.45 * * *$ & $71860.0 \mathrm{c}$ \\
\hline & & $40-60$ & $7 b$ & $16 a$ & $111 \mathrm{c}$ & $0.36 * * *$ & $0.88 * * *$ & $0.76^{* * *}$ & 20920.0b \\
\hline & & $60-80$ & $14 c$ & $18 \mathrm{~b}$ & $104 b$ & $0.81 * * *$ & $0.85 * * *$ & $0.81 * * *$ & $20250.0 \mathrm{a}$ \\
\hline
\end{tabular}

Correlation coefficients $\left(R^{2}\right)$ between the concentration of formed methane $\left(\mathrm{M}, \mathrm{mg} \mathrm{CH}_{4} \mathrm{~g} \mathrm{DW}^{-1}\right)$ and the oxygen diffusion rate $(\mathrm{ODR})$ as well as redox potential $(\mathrm{Eh})(\mathrm{n}=60)$ and methanogenic activity $(\mathrm{MGA})$ at aerated $(\mathrm{AT})$ and anaerobic $(\mathrm{AN})$ treatments Values followed by the same letter in particular treatments and temperatures across depth are not significantly different (ANOVA, $p>0.05)$

* Significant at $p<0.05, * *$ Significant at $p<0.01$, *** Significant at $p<0.001$

any investigated peat samples was found. In AT treatment methane at 20 and $10{ }^{\circ} \mathrm{C}$ was detected between the 35 th and 259 th days. At $5{ }^{\circ} \mathrm{C}$, despite the 300 days of experiment, no methane was found (Table 3). In AN samples the overall lag time for initiating methane production was significantly shorter (8-10-times) in comparison to AT (Fig. 4). Once methane production was detected, a further increase in its concentration in the headspace was observed (see Table 2 and Fig. 2). Furthermore, the incubations at 20, 10 , and $5{ }^{\circ} \mathrm{C}$ indicated that for the lower temperatures, methanogens required less oxygen (lower values of ODR and Eh) to initiate methane production $(p<0.001$, Table 3; Fig. 3). Decreasing temperatures and aeration increased the time until the initiation of $\mathrm{CH}_{4}$ production ( $p<0.05, \mathrm{n}=72$, Fig. 4). Lowering of temperature inhibits enzymatic activity and may also cause microbes to undergo physiological changes that result in reduced carbon and oxygen use efficiency (Frey et al. 2013). It is also possible that some groups of microorganisms cope better with temperature stress, deplete oxygen and create conditions (Eh and ODR values defined as critical) for methane production even at low temperatures.

Methanogenic activity (MGA) of investigated peats under AN treatment ranged from $20.3\left(5^{\circ} \mathrm{C}\right)$ to 71.860 $\left(20{ }^{\circ} \mathrm{C}\right) \mathrm{mg} \mathrm{CH}_{4} \mathrm{kgDW}^{-1} \cdot \mathrm{d}^{-1}$ and was influenced by temperature, treatment and depth (three-way ANOVA 
Table 4 Threshold Eh values for starting methane formation and methanogenic activity in different samples

\begin{tabular}{|c|c|c|c|c|}
\hline \multirow[t]{2}{*}{ Origin of the samples } & \multirow{2}{*}{$\begin{array}{l}\text { Threshold } \\
\text { Eh values } \\
\text { for } \mathrm{CH}_{4} \\
\text { production }\end{array}$} & \multicolumn{2}{|l|}{ Methanogenic activity } & \multirow[t]{2}{*}{ Authors } \\
\hline & & $\begin{array}{l}\text { Flux from surface } \\
\left(\mathrm{mg} \mathrm{CH}_{4} \mathrm{~m}^{-2} \mathrm{~d}^{-1}\right)^{\mathrm{a}} \\
\text { or concentration in } \\
\text { gas phase }\left(\mu \mathrm{g}^{-1}\right)^{\mathrm{b}}\end{array}$ & $\begin{array}{l}\text { By weight of } \\
\text { the sample } \\
\left(\mu \mathrm{gg}^{-1} \mathrm{~d}^{-1}\right)^{\mathrm{c}}\end{array}$ & \\
\hline Wetland soils (Alluga region, Germany) & -75 & $15-244^{\mathrm{a}}$ & - & Fiedler and Sommer (2000) \\
\hline Organic sediments (Denmark) & -90 & - & 23,040 & Grünfeld and Brix (1999) \\
\hline $\begin{array}{l}\text { Mangrove Sediment (Mzinga creek, } \\
\text { Tanzania) }\end{array}$ & -150 to -300 & $200^{\mathrm{a}}$ & - & Lyimo et al. (2002) \\
\hline Forest soil (Louisiana, USA) & +300 & $1.6-177.0^{\mathrm{b}}$ & - & Yu et al. 2006 \\
\hline Water bodies (Lucknow, India) & -150 & $91.2-1241.6^{\mathrm{a}}$ & - & Singh (2001) \\
\hline Rice paddy soils (Louisiana,USA) & +300 & - & $24-12,082$ & Yu and Patrick (2003) \\
\hline Paddy soils (Japan) & -150 & - & 495.36 & $\begin{array}{l}\text { Minamikawa and Sakai } \\
\text { (2005) }\end{array}$ \\
\hline $\begin{array}{l}\text { Rice soils: Arkansas, California, } \\
\text { Louisiana, Texas (USA); Hangzhou } \\
\text { (China), Java (Indonesia) }\end{array}$ & +400 & - & To 240 & Yu et al. (2007) \\
\hline $\begin{array}{l}\text { Methanothermobacter } \\
\text { thermautotrophicus in medium culture }\end{array}$ & -200 & - & - & Hirano et al. (2013) \\
\hline $\begin{array}{l}\text { Methanosarcina barkeri in medium } \\
\text { culture }\end{array}$ & +50 to +420 & - & - & Fetzer and Conrad (1993) \\
\hline Garbatówka fen (east Poland) & +240 to +112 & & $1.8-71,860$ & This study \\
\hline
\end{tabular}

${ }^{a}$ Flux from the surface

b Concentration in gas phase

c Data recalculated to common unit
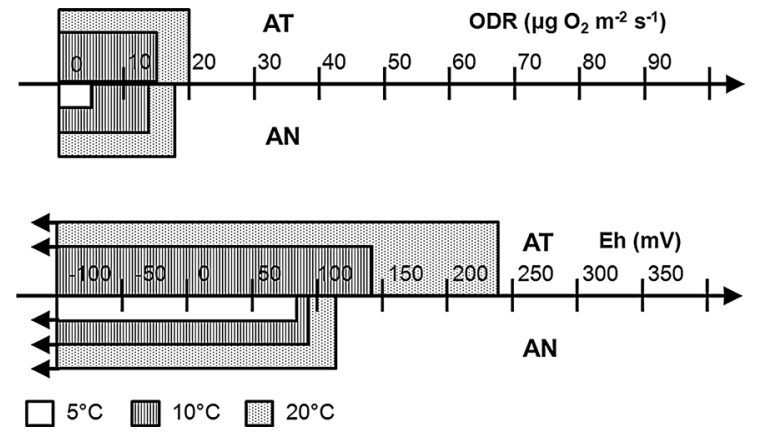

Fig. 3 The favourable ranges of ODR and Eh for methane production at 5,10 and $20{ }^{\circ} \mathrm{C}$ under aerated (AT) and anoxic (AN) treatments

test, $p<0.001)$. It was higher than in an organic sediment or rice paddy soils (Table 4) as well as a natural bog from Québec, Canada $\left(130 \mu \mathrm{g} \mathrm{CH}_{4}\right.$ $\mathrm{kgDW}^{-1} \cdot \mathrm{d}^{-1}$; Glatzel et al. 2004), acid bog from Germany $\left(6,400-27,200 \mu \mathrm{g} \mathrm{CH}_{4} \mathrm{kgDW}^{-1} \cdot \mathrm{d}^{-1}\right.$; Horn et al. 2003), freshwater marshes from Sanjiang Mire Wetland in China $\left(2-200 \mu \mathrm{g} \mathrm{CH}_{4} \mathrm{kgDW}^{-1} \cdot \mathrm{d}^{-1}\right.$; Liu et al. 2011) but was 3-times lower than in

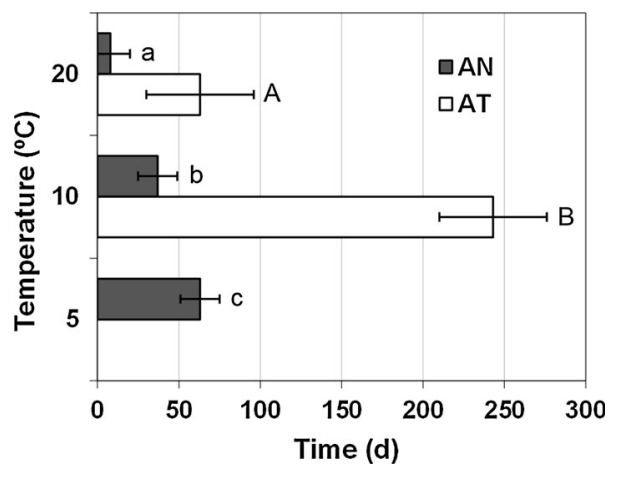

Fig. 4 Time of methanogenic activation at 5, 10, and $20^{\circ} \mathrm{C}$ $(n=72)$. Different letters above the bars refer to significant differences in the lag time among methanogenically active samples separately of AT and AN treatmetns $(p<0.05)$

ombrotrophic upland blanket peat at Lake Vyrnwy in the United Kingdom $\left(228,480 \mu \mathrm{g} \mathrm{CH}_{4} \mathrm{kgDW}^{-1} \cdot \mathrm{d}^{-1}\right.$; Freitag and Prosser 2009).

Soil aeration lowered the methanogenic activity of investigated peats from 28 to $100 \%(p<0.001$, Table 3). The stronger reduction at 5 and $10{ }^{\circ} \mathrm{C}$ (by 
98-100\%) while weaker (by $28-92 \%$ ) at $20{ }^{\circ} \mathrm{C}$ was noted. Similarly in mid-Wales wetland (UK) methane production after drought was reduced by $89 \%$ (Freeman et al. 2002) and after 4 week the lowering of the surface emission was from 1.21 to $0.28 \mathrm{mg} \mathrm{m}^{-2} \mathrm{~h}^{-1}$ (Dowrick et al. 2006). A short period of aeration (1 week) can either stimulate (by stimulation organic matter decomposition in presence of oxygen and increase of availability simple substrate for methanogenesis) or does not affect the methane production as was found in Dutch and Germany peats (Fenner and Freeman 2011; Brouns et al. 2014). But the longer the drought the higher reduction in methane emission was observed. The fact that methanogens can survive the periods of drought (e.g. 4 weeks) in some bogs, fens and riparian wetlands has been confirmed by molecular analysis. There were no differences in the diversity and composition of the microbial communities between control and drought (Kim et al. 2008). However, in rice paddy soils the growth of methanogenic populations, as revealed by mcrA gene abundance, was suppressed during the second dry/wet cycle (Ma et al. 2012).

Our results also revealed that in optimal temperature $\left(20{ }^{\circ} \mathrm{C}\right)$, surface $(0-20 \mathrm{~cm}$, AT), and subsurface (20-40 cm, AN) depths were associated with the highest methanogenic potential of $15,610 \mu \mathrm{g} \mathrm{CH}_{4} \mathrm{kgDW}^{-1} \cdot \mathrm{d}^{-1}$ and $71,860 \mu \mathrm{g} \quad \mathrm{CH}_{4} \quad \mathrm{kgDW}^{-1} \cdot \mathrm{d}^{-1}$, respectively $(p<0.001$, Table 3$)$. In 10 and $20{ }^{\circ} \mathrm{C}$ peat from level $0-20 \mathrm{~cm}$ was more resistant to oxygenation and the reduction of methanogenic activity was 87 and $28 \%$ (Table 2). The surface level of peatlands is often exposed to air due to groundwater table fluctuations, therefore the present methanogenic microorganisms could be adapted to the presence of oxygen, which could be transported also by plant root system e.g. Carex spp. and Phragmites spp. overgrowning investigated fen. Plants can also enhance methane production in surface layers by supplying fresh litter and exudates as a substrates for methanogenic microorganisms (Roura-Carol and Freeman 1999). Deeper layers of peat are more stable, permanently anoxic and probably inhabited mostly by microorganisms highly sensitive to oxygen (Glass and Orphan 2012; Knoblauch et al. 2008; Tholen et al. 2007).

\section{Conclusions}

We conducted research on peat soils under aerated and anoxic conditions and found that aeration parameters such as Eh or ODR are tightly coupled to methane production by methanogenic microbial communities. Methane concentration was negatively correlated with both Eh and ODR $(p<0.05)$. Our data suggest that methanogens inhabiting natural peats can survive the exposure to oxygen stress (ODR $>60 \mu \mathrm{g} \mathrm{O}_{2} \mathrm{~m}^{-2} \mathrm{~s}^{-1}$, $\mathrm{Eh}>+400 \mathrm{mV})$. We determined the Eh upper threshold of $+240 \mathrm{mV}$, for methane production in this peat. The corresponding threshold for ODR was $20 \mu \mathrm{g} \mathrm{O}_{2} \mathrm{~m}^{-2} \mathrm{~s}^{-1}$. These threshold values are higher than reported previously. We also showed that the temperature has significant influence on the aeration parameters. When the incubation temperature decreased (from 20 to 10 or $5{ }^{\circ} \mathrm{C}$ ), the aeration thresholds required for methane synthesis also decreased. The time needed for creation conditions suitable for methane production varied between 3 and 259 days, depending on the temperature and treatment. These results suggest that methanogens survived stress caused by oxygen and temperature with exception of the $5{ }^{\circ} \mathrm{C}$ AT treatment when no methane was found during the 300 days of the experiment. Stress caused by aerated conditions resulted in a decrease in the methanogenic activity from 28 to $100 \%$ relative to the anoxic treatment. Finally, we found that methanogenic activity was dependent on the depth in the peat soil profile. Approximately four times higher activity was observed in the surface $(0-40 \mathrm{~cm})$, compared with the deeper $(40-80 \mathrm{~cm})$ layers.

To our knowledge, this is the first study which directly links ODR to methane production potential. ODR was found to be a useful technique for estimating the methanogenic potential of organic soils, and showed statistically significant negative relationships between ODR and methane production as well as between ODR and Eh $(p<0.001)$. The measurement of $\mathrm{O}_{2}$ availability in soils by ODR can provide further insight into the dynamics of methane cycling in the field. The future studies should be conducted in order to confirm the usefulness of ODR technique in other types of wetlands. The relationships reported here between ODR/Eh and methanogenic activity can be potentially incorporated into predictive models for methane emission from peat soils and be useful for testing future methane emission scenarios based on Eh and ODR predictions in the changing climate.

Acknowledgments The work was supported by the Polish Ministry of Science and Higher Education, Grants NoS. N304 102 32/3859 and N305 299 440. We acknowledge Dr. 
A. Banach for his invaluable assistance in statistical analysis. The authors thank as well their colleague at UC Berkeley, as P. Salierno $\mathrm{PhD}$ and R. Yuswack M. Sc. for proofreading the article.

Open Access This article is distributed under the terms of the Creative Commons Attribution License which permits any use, distribution, and reproduction in any medium, provided the original author(s) and the source are credited.

\section{References}

Angel R, Matthies D, Conrad R (2011) Activation of methanogenesis in arid biological soil crusts despite the presence of oxygen. PLoS One 6(5):e20453. doi:10.1371/ journal.pone.0020453

Banach AM, Banach K, Visser EJW, Stępniewska Z, Smits AJM, Roelofs JGM, Lamers LPM (2009) Effects of summer flooding on floodplain biogeochemistry in Poland; implications for increased flooding frequency. Biogeochemistry 92:247-262

Bennicelli RP, Szafranek A, Stępniewska Z (2006) Influence of redox conditions on methane release from peat soils. Proc ISTRO 17:1114-1119. ISBN 3-9811134-0-3

Brouns K, Verhoeven JTA, Hefting MM (2014) Short period of oxygenation releases latch on peat decomposition. Sci Total Environ 481:61-68

Brune A, Frenzel P, Cypionka H (2000) Life at the oxic-anxic interface: microbial activities and adaptations. FEMS Microbiol Ecol 24:691-710

Czyż E (2004) Effects of traffic on soil aeration, bulk density and growth of spring barley. Soil Tillage Res 79:153-166

Demirel B, Scherer P (2008) The roles of acetotrophic and hydrogenotrophic methanogens during anaerobic conversion of biomass to methane: a review. Rev Environ Sci Biotechnol 7:173-190

Dowrick DJ, Freeman C, Lock MA, Reynolds B (2006) Sulphate reduction and the suppression of peatland methane emissions following summer drought. Geoderma 132:384-390

Erkel C, Kube M, Reinhardt R, Liesack W (2006) Genome of rice cluster I Archaea-the key methane producers in the rice rhizosphere. Sci 313:370-372

Fenner N, Freeman C (2011) Drought-induced carbon loss in peatlands. Nat Geosci 4:895-900. doi:10.1038/ngeo1323

Fetzer S, Conrad R (1993) Effect of redox potential on methanogenesis by Methanosarcina barkeri. Archaeal Microbiol 160:108-113

Fiedler S, Sommer M (2000) Methane emissions, groundwater levels and redox potentials of common wetland soils in a temperate-humid climate. Global Biogeochem Cycles 14(4):1081-1093

Forster P, Ramaswamy V, Artaxo P, Berntsen T, Betts R, Fahey DW, Haywood J, Lean J, Lowe DC, Myhre G, Nganga J, Prinn R, Raga G, Schulz M, Van Dorland R (2007) Changes in atmospheric constituents and in radiative forcing. In: Solomon S, Qin D, Manning M, Chen Z, Marquis M, Averyt KB, Tignor M, Miller HL (eds) Climate change 2007: the physical science basis. contribution of working group $i$ to the fourth assessment report of the intergovernmental panel on climate change. Cambridge University Press, Cambridge, pp 131-234

Freeman C, Nevison GB, Kang H, Hughes S, Reynolds B, Hudson JA (2002) Contrasted effect of stimulated drought on the production and oxidation of methane in a mid-Wales wetland. Soil Biol Biochem 34:61-67

Freitag TE, Prosser JI (2009) Correlation of methane production and functional gene transcriptional activity in a peat soil. Appl Environ Microb 75(21):6679-6687

Frey SD, Lee J, Melillo JM, Six J (2013) The temperature response of soil microbial efficiency and its feedback to climate. Nat Clim Change 3:395-398

Glass JB, Orphan VJ (2012) Trace metal requirements for microbial enzymes involved in the production and consumption of methane and nitrous oxide. Front Microbiol 3:61

Glatzel S, Basiliko N, Moore T (2004) Carbon dioxide and methane production potential of peats from natural, harvested and restored sites, eastern Québec, Canada. Wetlands 24(2):261-267

Grossart HP, Frindte K, Dziallas C, Eckert W, Tang KW (2011) Microbial methane production in oxygenated water column of an oligotrophic lake. Proc Natl Acad Sci USA 108:19657-19661

Grünfeld S, Brix H (1999) Methanogenesis and methane emissions: effects of water table, substrate type and presence of Phragmites australis. Aquat Bot 64:63-75

Hirano S, Matsumoto N, Morita M, Sasaki K, Ohmura N (2013) Electrochemical control of redox potential affects methanogenesis of the hydrogenotrophic methanogen Methanothermobacter thermautotrophicus. Lett Appl Microbiol 56:315-321

Horn MA, Matthies C, Kusel K, Schramm A, Drake HL (2003) Hydrogenotrophic methanogenesis by moderately acidtolerant methanogens of a methane-emitting acidic peat. Appl Environ Microbiol 69(1):74-83

Inglett PW, Reddy KR, Corstanje R (2005) Anaerobic soils. In: Hillel D (ed) Encyclopedia of soils in the environment. Academic Press, London, pp 72-78

Kechavarzi C, Dawson Q, Bartlett M, Leeds-Harrison PB (2010) The role of soil moisture, temperature and nutrient amendment on $\mathrm{CO}_{2}$ efflux from agricultural peat soil microcosms. Geoderma 154:203-210

Kim SY, Lee SH, Freeman C, Fenner N, Kang H (2008) Comparative analysis of soil microbial communities and their responses to the short-term drought in bog, fen and riparian wetlands. Soil Biol Biochem 40:2874-2880

Knoblauch C, Zimmermann U, Blumenberg M, Michaelis W, Pfeiffer EM (2008) Methane turnover and temperature response of methane-oxidizing bacteria in permafrost-affected soils of northeast Siberia. Soil Biol Biochem 40:3004-3013

Lemon ER, Erickson AE (1952) The measurement of oxygen diffusion in the soil with platinum microelectrode. Soil Sci Soc Am J 16:160-163

Liu DY, Ding WX, Jia ZJ, Cai ZC (2011) Relation between methanogenic archaea and methane production potential in selected natural wetland ecosystems across China. Biogeosciences 8:329-338

Lyimo TJ, Pol A, Op den Camp HJM (2002) Methane emission, sulphide concentration and redox potential profiles in 
Mtoni Mangrove Sediment, Tanzania. Western Indian Ocean J Mar Sci 1(1):71-80

Ma K, Conra R, Lua Y (2012) Responses of methanogen mcrA genes and their Transcripts to an alternate dry/wet cycle of paddy field soil. Appl Environ Microbiol 78(2):445-454

Minamikawa K, Sakai N (2005) The effect of water management based on soil redox potential on methane emission from two kinds of paddy soils in Japan. Agric Ecosyst Environ 107:397-407

Morozova D, Wagner D (2007) Stress response of methanogenic archaea from Siberian permafrost compared with methanogens from nonpermafrost habitats. FEMS Microbiol Ecol 61:16-25

Öquist M, Sundh I (1998) Effect of a transient oxic period on mineralization of organic matter to $\mathrm{CH}_{4}$ and $\mathrm{CO}_{2}$ in anoxic peat incubations. Geomicrobiol J 15(4):325-333

Pezeshki SR (2001) Wetland plant response to soil flooding. Environ Exp Bot 46:299-312

Riutta T (2008) Fen ecosystem carbon gas dynamics in changing hydrological conditions. Dissertations Forestales 67, p 46. ISBN 978-951-651-222-1 (PDF)

Roura-Carol M, Freeman C (1999) Methane release from peat soils: effects of Sphagnum and Juncus. Soil Biol Biochem 31:323-325

Singh SN (2001) Exploring correlation between redox potential and other edaphic factors in field and laboratory conditions in relation to methane efflux. Environ Int 27:265-274

Stępniewski W, Stępniewska Z, Przywara G, Brzezińska M, Włodarczyk T, Várallyay G (2000) Relations between aeration status and physical parameters of some selected Hungarian soils. Int Agrophys 14:439-447
Stępniewski W, Stępniewska Z, Bennicelli RP, Gliński J (2005) Soil oxygenology. In: Stępniewski W et al (eds) Oxygenology in outline. Institute of Agrophisics PAS, Lublin, pp 35-64

Szafranek-Nakonieczna A, Bennicelli RP (2010) Ability of peat soil to oxidize methane and effect of temperature and layer deposition. Pol J Environ Stud 19(4):805-810

Tholen A, Pester M, Brune A (2007) Simultaneous methanogenesis and oxygen reduction by Methanobrevibacter cuticularis at low oxygen fluxes. FEMS Microbiol Ecol 62:303-312

Yao H, Conrad R, Wassmann R, Neue HU (1999) Effect of soil characteristics on sequential reduction and methane production in sixteen rice paddy soils from China, the Philippines, and Italy. Biogeochemistry 47:269-295

Yu KW, Patrick WH Jr (2003) Redox range with minimum nitrous oxide and methane production in a rice soil under different pH. Soil Sci Soc Am J 67:1952-1958

Yu KW, Faulkner SP, Patrick WH Jr (2006) Redox potential characterization and soil greenhouse gas concentration across a hydrological gradient in a Gulf coast forest. Chemosphere 62:905-914

Yu K, Böhme F, Rinklebe J, Neue H-U, DeLaune RD (2007) Major biogeochemical processes in soils-a microcosm incubation from reducing to oxidizing conditions. Soil Sci Soc Am J 71:1406-1417

Yuan Y, Conrad R, Lu Y (2009) Responses of methanogenic archaeal community to oxygen exposure in rice field soil. Environ Microbiol Rep 1:347-354 